\title{
Profil lesi oral pada penderita penyakit autoimun
}

Indah Suasani Wahyuni, Tenny Setiani Dewi, Erna Herawati, Dewi Zakiawati

Departemen Ilmu Penyakit Mulut, Fakultas Kedokteran Gigi, Universitas Padjadjaran, Jawa Barat, Indonesia

JI Raya Bandung Sumedang Km. 21, Jatinangor, Jawa Barat, Indonesia; e-mail: Indah.wahyuni@fkg.unpad.ac.id

Submisi: 20 Mei 2016; Penerimaan: 21 September 2016

\begin{abstract}
ABSTRAK
Lesi oral biasa ditemukan pada penderita penyakit autoimun sebagai manifestasi penyakit atau efek samping pengobatan kortikosteroid jangka panjang. Lesi oral harus ditangani dengan baik untuk mencegah terjadinya infeksi sekunder, mengatasi rasa sakit dan meningkatkan kualitas hidup penderita. Pengumpulan data gambaran profil lesi oral penderita penyakit autoimun, meliputi karakteristik klinis dan lokasi lesi oral serta distribusi usia dan jenis kelamin penderita belum pernah dilakukan. Metode yang digunakan adalah non eksperimen, retrospektif dan deskripsi data sekunder penderita autoimun yang ditangani oleh bagian IImu Penyakit Mulut FKG Universitas Padjadjaran di SMF Gigi dan Mulut RS dr. Hasan Sadikin Bandung. Data pasien yang dipergunakan antara bulan Agustus 2010 sampai Agustus 2014 ( $n=66$ ), dengan diagnosis penyakit autoimun yang paling sering adalah Sistemic Lupus Erythematous (SLE), Oral Lichen Planus (OLP) dan Pemphigus Vulgaris (PV). Semua pasien memberikan persetujuan pada saat dilakukan pemeriksaan dan pengumpulan data melalui informed consent. Hasil penelitian ini menunjukkan usia penderita bervariasi antara 9 hingga 68 tahun dan jumlah penderita wanita lebih banyak daripada pria. Penderita yang didiagnosis SLE 26 orang $(39,4 \%)$, OLP 12 orang $(18,2 \%)$ dan PV 28 orang $(42,4 \%)$. Berdasarkan gambaran klinisnya jenis lesi oral yang banyak ditemukan adalah erosi $(n=52 / 78,8 \%)$ dan berdasarkan lokasi lesi oral banyak ditemukan pada mukosa bukal $(n=46 / 69,7 \%$ penderita). Kesimpulannya, pemeriksaan intra oral disarankan menjadi prosedur rutin dalam tatalaksana komprehensif penderita penyakit autoimun. Dokter gigi diharapkan dapat berperan dalam mendiagnosis lesi oral dan memberikan terapi yang tepat sehingga dapat meningkatkan kualitas hidup penderita penyakit autoimun.
\end{abstract}

Kata kunci: lesi oral, penyakit autoimun, Oral Lichen Planus, Pemphigus Vulgaris, Sistemic Lupus Erythematous

\begin{abstract}
Oral lesion's profile in autoimmune disease. Oral lesions are commonly found in patients with autoimmune diseases as manifestations of the disease or a side effect of the treatment. Oral lesions must be handled properly to prevent secondary infection, relieve pain and improve the patient's quality of life. The aim of this study is to describe oral lesions profile in patients with autoimmune diseases, including clinical characteristics and location of oral lesions as well as the distribution of age and sex of the patient. The methods were retrospective observation by describing the secondary data from patients with autoimmune handled by Oral Medicine Specialist, Faculty of Dentistry, University of Padjadjaran in dr. Hasan Sadikin Hospital Dental Clinic. Patient files from August 2010 untill August 2014 $(n=66)$ were used, with the most often diagnosis were Systemic Lupus erythematosus (SLE), Oral lichen planus (OLP) and Pemphigus vulgaris (PV). It is revealed that, the age of patients varied between 9 to 68 years old and there was predominance of female patients. Patients diagnosed with SLE were 26 (39.4\%), 12 patients with OLP (18.2\%) and 28 patients with PV (42.4\%). Based on the clinical feature, the most commonly found type of oral lesion was erosion ( $n=52 / 78,8 \%$ ), while the most commonly predilection was in the buccal mucosa ( $n=46 / 69,7 \%)$. In conclusion, intra-oral examination should be used as a routine procedure in the comprehensive management of patients with autoimmune diseases. Dentist have a professional role in the diagnosis of oral lesions and provide appropriate therapy in order to improve the quality of life of patients with autoimmune diseases.
\end{abstract}

Keywords: oral lesion, Autoimmune disease, Oral Lichen Planus, Pemphigus Vulgaris, Sistemic Lupus Erythematous

\section{PENDAHULUAN}

Penyakit autoimun adalah penyakit yang dapat mengenai mukosa oral dan kulit atau organ lain, akibat kesalahan tubuh dalam mengenali sel diri sendiri (self) menjadi antigen. Sistem kekebalan yang seharusnya berfungsi sebagai pelindung tubuh mengalami kelainan sehingga tidak dapat membedakan antara benda asing yang harus dimusnahkan dengan jaringan tubuh sendiri yang bermanfaat untuk kelangsungan hidup. ${ }^{1-3}$

Penyebab penyakit autoimun belum diketahui secara pasti, namun perjalanan penyakit ini dapat akut atau kronis dan terdapat masa remisi atau 
eksaserbasi yang disertai dengan perubahan level autoantibodi dalam tubuh. Kombinasi faktor predisposisi genetik dan faktor lingkungan diketahui melalui berbagai referensi berkontribusi terhadap perkembangan penyakit autoimun. ${ }^{1-5}$

Lesi oral biasa ditemukan pada penderita penyakit autoimun sebagai manifestasi penyakit atau efek samping pengobatan. Penyakit autoimun yang dapat bermanifestasi pada rongga mulut di antaranya adalah Sistemic Lupus Erythematous (SLE), Lichen Planus, Pemfigus dan Pemfigoid. Lesi oral yang merupakan manifestasi penyakit autoimun dapat menunjukkan tanda klinis berupa ulser, erosi, vesikobulosa, plak atau papula, dan lain-lain. Lesi oral harus ditangani dengan baik untuk mencegah terjadinya infeksi sekunder, mengatasi rasa sakit dan meningkatkan kualitas hidup penderita. ${ }^{6-9}$

Tujuan penelitian ini untuk mengetahui dan mendeskripsikan profil lesi oral pada penderita penyakit autoimun yang belum pernah dimiliki oleh Departemen Gigi dan Mulut RS dr. Hasan Sadikin Bandung/Sub bagian IImu Penyakit Mulut, yaitu meliputi karakteristik klinis dan lokasi lesi oral serta distribusi usia, jenis kelamin dan jenis penyakit autoimun subjek penelitian. Hasil penelitiandiharapkan dapat menjadi dasar penelitian epidemiologi lesi oral dan pengembangan pengobatan lesi oral lebih lanjut bagi penderita penyakit autoimun.

\section{METODE PENELITIAN}

Metode penelitian yang digunakan adalah non eksperimen, retrospektif dan deskripsi data sekunder penderita autoimun yang ditangani oleh bagian IImu Penyakit Mulut FKG Universitas Padjadjaran di SMF Gigi dan Mulut RS dr. Hasan Sadikin Bandung. Data yang dipergunakan dalam penelitian ini adalah data pasien antara bulan Agustus 2010 sampai Agustus 2014, dengan diagnosis penyakit autoimun. Seluruh pasien memberikan persetujuannya dalam bentuk informed consent pada saat dilaksanakan pemeriksaan primer dan pencatatan data, penelitian ini juga bersifat non invasif sehingga tidak diajukan permohonan ethical clearance dari instansi terkait setempat. Data yang dikumpulkan untuk penelitian ini merupakan data sekunder, meliputi profil pasien berupa usia, jenis kelamin dan jenis penyakit autoimun serta profil lesi oral meliputi jenis dan lokasi lesi oral. Semua data yang memenuhi kriteria yaitu yang tercatat lengkap dalam status pasien bagian ilmu penyakit mulut, disusun dalam suatu tabel dan diolah secara kuantitatif menggunakan program excel office. Diagnosa penyakit mulut dalam hal ini Oral Lichen Planus ditegakkan oleh dokter gigi spesialis penyakit mulut, sedangkan diagnosa penyakit autoimun SLE ditegakkan oleh dokter spesialis penyakit dalam/rheumatologi dan diagnosa pemfigus vulgaris ditegakkan oleh dokter spesialis penyakit kulit dan kelamin. Hasil penghitungan jenis dan lokasi lesi oral secara kuantitatif selanjutnya dideskripsikan berdasarkan kelompok penyakit autoimun.

\section{HASIL PENELITIAN}

Berdasarkan profil penderita penyakit autoimun yang ditangani oleh bagian IImu Penyakit Mulut FKG Unpad di SMF Gigi dan Mulut RS Dr. Hasan Sadikin Bandung, maka didapatkan bahwa kecenderungan terjadinya penyakit autoimun lebih banyak ditemukan pada wanita yaitu $75,8 \%$ sedangkan pada pria $24,2 \%$. Pembagian kelompok usia didasarkan pada kategori anak - anak hingga usia 18 tahun $(n=5)$, usia dewasa 18 hingga usia 60 tahun $(n=56)$ dan usia lanjut mulai 60 tahun dan seterusnya $(n=5)$. Tabel jumlah dan persentase jenis kelamin serta kelompok usia penderita autoimun seperti tampak pada Tabel 1.

Pada penelitian ini terdapat 5 orang $(7,6 \%)$ termasuk dalam kelompok usia anak anak $<18$ tahun yang kesemuanya adalah penderita Sistemic Lupus Erythematous (SLE), 5 orang $(7,6 \%)$ kelompok usia $>60$ tahun (4 penderita Oral Lichen Planus (OLP) dan 1 penderita Pemfigus Vulgaris) dan sebagian besar penderita termasuk dalam kelompok usia 18 hingga $<60$ tahun yaitu sebanyak 56 orang $(84,8 \%)$. Penderita SLE dan Pemfigus pada penelitian ini sebagian besar adalah wanita (92,3\% dan $71,4 \%)$, sedangkan pada penderita oral lichen planus tidak ada perbedaan antara pria dan wanita. Distribusi kelompok usia dan jenis kelamin berdasarkan kelompok penyakit autoimun seperti tampak pada Tabel 2. 
Tabel 1. Profil penderita penyakit autoimun

\begin{tabular}{lccccc}
\hline \multirow{2}{*}{$\mathrm{n}=66$} & \multicolumn{3}{c}{ Jenis Kelamin } & \multicolumn{3}{c}{ Kelompok Usia } \\
\cline { 2 - 6 } & Pria & Wanita & $<18$ tahun & $18-<60$ tahun & 60 tahun \\
\hline jumlah & 16 & 50 & 5 & 56 & 5 \\
persentase & $24.2 \%$ & $\mathbf{7 5 . 8 \%}$ & $7.6 \%$ & $\mathbf{8 4 . 8 \%}$ & $7.6 \%$ \\
\hline
\end{tabular}

Tabel 2. Distribusi kelompok usia dan jenis kelamin pada penderita penyakit autoimun

\begin{tabular}{|c|c|c|c|c|c|c|c|c|c|}
\hline \multirow[b]{3}{*}{ kelompok usia } & \multicolumn{9}{|c|}{ Penyakit Autoimun } \\
\hline & \multicolumn{3}{|c|}{$\begin{array}{l}\text { Lupus Erythematosus } \\
\qquad(\mathrm{n}=26)\end{array}$} & \multicolumn{3}{|c|}{$\begin{array}{c}\text { Oral Lichen Planus } \\
(n=12)\end{array}$} & \multicolumn{3}{|c|}{$\begin{array}{l}\text { Pemfigus } \\
(\mathrm{n}=28)\end{array}$} \\
\hline & $<18$ & $18-<60$ & $60 \sim$ & $<18$ & $18-<60$ & $60 \sim$ & $<18$ & $18-<60$ & $60 \sim$ \\
\hline Jumlah & 5 & 21 & 0 & 0 & 8 & 4 & 0 & 27 & 1 \\
\hline persentase & $19,2 \%$ & $80,8 \%$ & $0 \%$ & $0 \%$ & $66,6 \%$ & $33,4 \%$ & $0 \%$ & $96,4 \%$ & $3,6 \%$ \\
\hline jenis kelamin & Pria & \multicolumn{2}{|c|}{ Wanita } & Pria & \multicolumn{2}{|c|}{ Wanita } & Pria & \multicolumn{2}{|c|}{ Wanita } \\
\hline Jumlah & 2 & \multicolumn{2}{|c|}{24} & 6 & \multicolumn{2}{|c|}{6} & 8 & \multicolumn{2}{|c|}{20} \\
\hline persentase & $7.7 \%$ & \multicolumn{2}{|c|}{$92.3 \%$} & $50 \%$ & \multicolumn{2}{|c|}{$50 \%$} & $28.6 \%$ & \multicolumn{2}{|c|}{$71.4 \%$} \\
\hline
\end{tabular}

Tabel 3. Profil lesi oral pada penderita penyakit autoimun

\begin{tabular}{|c|c|c|c|c|c|c|c|c|c|c|c|c|c|c|c|c|c|c|}
\hline \multirow{2}{*}{$\begin{array}{c}\text { SLE } \\
(n=26)\end{array}$} & \multicolumn{10}{|c|}{ Lokasi Lesi Oral } & \multicolumn{8}{|c|}{ Jenis Lesi Oral } \\
\hline & $\mathrm{Bi}$ & $\mathrm{Lb}$ & Bk & $\mathrm{DL}$ & $\overline{V L}$ & PD & PM & DM & $\mathrm{Gu}$ & LL & $\mathrm{PI}$ & $S$ & $\mathrm{E}$ & $U$ & $\mathrm{~F}$ & $\mathrm{Pt}$ & $\mathrm{D}$ & $\mathrm{K}$ \\
\hline jumlah & 7 & 13 & 13 & 12 & 5 & 11 & 4 & 0 & 5 & 1 & 6 & 0 & 17 & 13 & 1 & 2 & 7 & 15 \\
\hline OLP & \multicolumn{10}{|c|}{ Lokasi Lesi Oral } & \multicolumn{8}{|c|}{ Jenis Lesi Oral } \\
\hline$(n=12)$ & $\mathrm{Bi}$ & $\mathrm{Lb}$ & $\mathrm{Bk}$ & $\mathrm{DL}$ & $\mathrm{VL}$ & $\mathrm{PD}$ & PM & $\mathrm{DM}$ & $\mathrm{Gu}$ & $\mathrm{LL}$ & $\mathrm{PI}$ & $\mathrm{S}$ & $\mathrm{E}$ & $\mathrm{U}$ & $\mathrm{F}$ & $\mathrm{Pt}$ & $D$ & $\mathrm{~K}$ \\
\hline jumlah & 4 & 7 & 8 & 8 & 2 & 0 & 0 & 0 & 5 & 0 & 7 & 5 & 10 & 2 & 0 & 0 & 0 & 7 \\
\hline $\mathrm{PV}$ & \multicolumn{10}{|c|}{ Lokasi Lesi Oral } & \multicolumn{8}{|c|}{ Jenis Lesi Oral } \\
\hline$(n=28)$ & $\mathrm{Bi}$ & $\mathrm{Lb}$ & $\mathrm{Bk}$ & $\mathrm{DL}$ & $\mathrm{VL}$ & $\mathrm{PD}$ & PM & $\mathrm{DM}$ & $\mathrm{Gu}$ & $\mathrm{LL}$ & $\mathrm{PI}$ & $S$ & $E$ & $\mathrm{U}$ & $\mathrm{F}$ & $\mathrm{Pt}$ & $D$ & $\mathrm{~K}$ \\
\hline jumlah & 13 & 21 & 25 & 23 & 9 & 12 & 12 & 1 & 13 & 0 & 8 & 4 & 25 & 9 & 0 & 0 & 6 & 17 \\
\hline
\end{tabular}

Keterangan: $\mathrm{Bi}=$ Bibir, $\mathrm{Lb}=$ Labial, $\mathrm{Bk}=$ Bukal, $\mathrm{DL}=$ Dorsum lidah, $\mathrm{VL}=$ Ventral lidah, $\mathrm{PD}=$ Palatum durum, $\mathrm{PM}=\mathrm{Palatum}$ molle, $\mathrm{DM}$ $=$ Dasar mulut, $\mathrm{Gu}=$ Gusi, $\mathrm{LL}=$ Lateral lidah. $\mathrm{PI}=$ Plak, $\mathrm{S}=\mathrm{Striae}, \mathrm{E}=\mathrm{Erosi}, \mathrm{U}=\mathrm{Ulser}, \mathrm{F}=$ Fissure $, \mathrm{Pt}=\mathrm{Ptechiae}, \mathrm{D}=$ Deskuamasi, $\mathrm{K}=$ Kombinasi

Gambaran klinis lesi oral pada penderita SLE yang ditemukan pada penelitian ini sebagian besar berlokasi pada mukosa labial $(n=13)$ dan mukosa bukal $(n=13)$, diikuti oleh dorsum lidah $(n=12)$ dan palatum durum $(n=11)$, sedangkan jenis lesi oral yang paling banyak ditemukan adalah erosi $(n=17)$ dan ulser $(n=13)$ atau kombinasi keduanya.

Lesi oral yang banyak ditemukan pada penderita Oral Lichen Planus pada penelitian ini adalah sebagian besar berlokasi pada mukosa bukal $(n=8)$ dan dorsum lidah $(n=8)$, diikuti oleh mukosa labial $(n=7)$, sedangkan jenis lesi oral yang paling banyak ditemukan adalah erosi $(n=10)$, diikuti oleh plak dan kombinasi antara beberapa jenis lesi seperti erosi dan plak atau erosi dan striae. Lesi striae yang merupakan gambaran khas OLP ditemukan pada 5 penderita.

Lesi oral penderita Pemfigus yang paling banyak ditemukan adalah erosi $(n=25)$, dan kombinasi erosi $\sim$ ulser atau erosi $\sim$ plak $(n=17)$. Sebagian besar lesi tersebut berlokasi di mukosa bukal $(n=25)$, dorsum lidah $(n=23)$ dan mukosa labial $(n=21)$. Profil lesi oral pada penderita penyakit autoimun seperti terangkum dalam Tabel 3 .

\section{PEMBAHASAN}

Kecenderungan terjadinya penyakit autoimun menurut beberapa penelitian lebih banyak ditemukan pada wanita dibandingkan dengan pria, demikian juga dengan hasil penelitian ini dari 
seluruh penderita penyakit autoimun yang ditangani sebanyak $75,8 \%$ wanita, sedangkan pria $24,2 \%$. Penderita Sistemik Lupus erythematosus (SLE) 92,3\% wanita, Oral Lichen Planus (OLP) 50\% wanita dan Pemfigus Vulgaris (PV) $71,4 \%$ wanita. Sebagian besar penderita termasuk dalam kelompok usia 18 hingga $<60$ tahun yaitu sebanyak 56 orang $(84,8 \%)$, baik pada kasus SLE $(80,8 \%)$, OLP $(66,6 \%)$ maupun PV (96,4\%). Hal ini sejalan dengan beberapa penelitian mengenai epidemiologi penyakit autoimun di beberapa negara, yaitu lebih banyak mengenai wanita daripada pria (pada kasus SLE rasio wanita: pria adalah 9:1) dan pada usia dewasa (18 hingga $<60$ tahun) ${ }^{1,6,10,11}$ Wanita dianggap lebih perhatian dan peduli terhadap kesehatan mulutnya sehingga mendorong untuk datang berobat ke dokter, ${ }^{12}$ selain itu wanita dipengaruhi oleh siklus hormonal. Pada saat kehamilan dan menstruasi kontribusi estrogen menyebabkan ketidakseimbangan hormonal dan memicu munculnya penyakit autoimun. . $^{2,313}$

Hubungan antara sekresi hormon dengan terjadinya penyakit autoimun sudah banyak diketahui dan disebutkan dalam beberapa referensi. Hormon merupakan komponen sistem neuroendokrin yang dapat mempengaruhi imunitas seseorang, sehingga jika terjadi ketidak seimbangan sintesis dan pelepasan hormonal, maka hormon akan beraksi sebagai stimulator atau supresor aktifitas imun dan neuroendokrin itu sendiri, dengan cara berikatan pada reseptor. Hormon juga berperan dalam respon imun innate dan adaptif. Hormon estrogen dan prolaktin merupakan sitokin pro inflamasi yang fluktuasinya dapat mengganggu toleransi terhadap sel sendiri (self), sehingga dapat menjadi faktor pemicu penyakit autoimun.,3

Penelitian oleh Arisawa et al., menemukan bahwa kasus Oral Lichen Planus sebagian besar mengenai wanita $(87,8 \%)$ namun pada kasus Pemfigus tidak menunjukkan kecenderungan gender. Kasus Oral lichen planus 50\% terjadi pada dekade kehidupan ke - 4 hingga ke - 5 (termuda 16 tahun, tertua 65 tahun), sedangkan kasus Pemfigus jarang ditemukan pada usia anak - anak namun banyak terjadi pada dekade kehidupan ke -4 atau usia dewasa. ${ }^{6,13}$

Gambaran klinis lesi oral pada penderita lupus erythematosus yang ditemukan pada penelitian ini adalah sebagian besar berlokasi pada mukosa labial $(50 \%)$ dan mukosa bukal $(50 \%)$, diikuti oleh dorsum lidah $(46,2 \%)$ dan palatum durum $(42,3 \%)$. Hal ini diduga karena bagian - bagian mukosa tersebut adalah bagian yang berkontak langsung atau bersentuhan dengan makanan dan gigi selama proses mengunyah dan berbicara, sehingga bagian tersebut paling sering terkena gesekan atau tekanan. Gesekan atau tekanan saat fungsi mengunyah atau berbicara pada lesi oral akibat penyakit autoimun akan membuat mukosa lebih rentan, memperparah kondisi lesi dan menyulitkan penyembuhan. ${ }^{1,6}$

Lesi oral yang merupakan manifestasi SLE di antaranya adalah lesi oral discoid dan ulserasi yang sangat sakit. Lesi oral discoid mirip dengan lesi discoid pada kulit yaitu terdapat gambaran striae berwarna putih yang memancar dari pusat lesi berwarna kemerahan (brush border). Predileksi lesi intra oral SLE ditemukan pada mukosa bukal, gusi dan mukosa labial serta daerah kemerahan yang terlokalisir terutama di daerah palatum..$^{1,7-9}$

Gambaran khas lesi OLP berupa striae atau gambaran renda berupa plak yang menempel pada mukosa oral, tidak bisa diangkat dengan kasa dan berwarna putih (Gambar 1). Pada penelitian ini banyak ditemukan lesi erosi $(83,3 \%)$ yang berkombinasi dengan lesi striae $(33,3 \%)$ atau plak $(41,6 \%)$, lesi erosi ini menimbulkan rasa sakit, sehingga membawa pasien berkunjung ke dokter gigi, sedangkan jika tidak terdapat erosi maka biasanya bersifat asimptomatik. Hasil penelitian ini berbeda dengan penelitian yang dilakukan oleh Arisawa, et.al., menemukan bahwa lesi yang banyak ditemukan adalah papul atau plak (83\%), disertai dengan gambaran retikuler/striae (57\%) dan $41 \%$ penderita mengeluhkan sakit. ${ }^{6}$ Faktor pencetus lesi OLP diduga adalah tambalan amalgam, jika tambalan tersebut diganti dengan tambalan non logam maka pada beberapa kasus akan berangsur angsur sembuh. Diagnosis banding OLP adalah Oral lichenoid reaction (OLR), OLP biasa terjadi bilateral dan OLR sering terjadi unilateral atau berhadapan dengan faktor pencetus yaitu tambalan amalgam, jika tambalan amalgam tersebut dihilangkan dan diberikan terapi topikal gel antiinflamasi maka lesi OLR akan segera menghilang. ${ }^{1,10,11}$ 

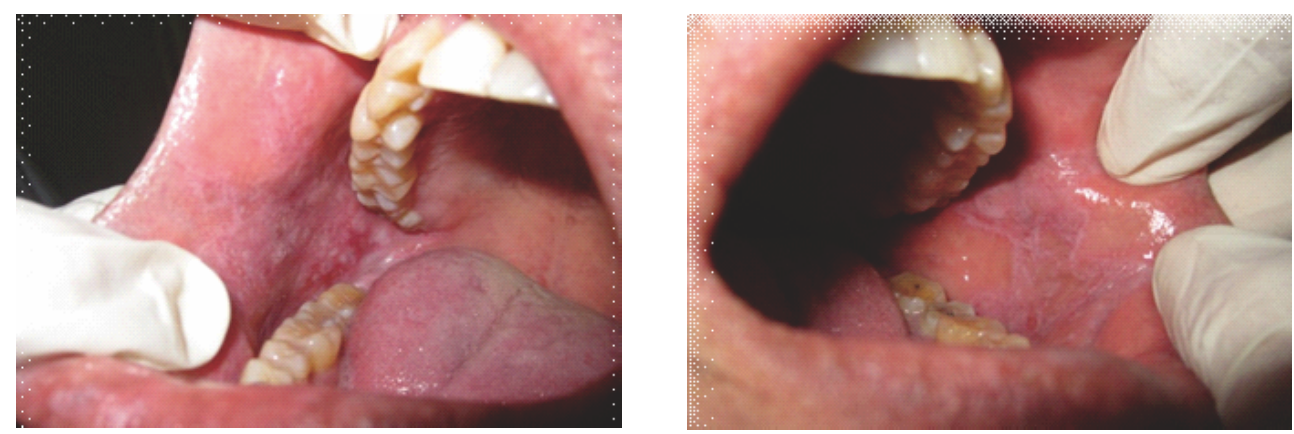

Gambar 1. Gambaran Khas Lesi OLP Plak Retikuler berwarna putih, Bilateral dan tidak dapat dengan kasa (dok.RSHS/sub bagian IPM)

Topikal steroid diberikan pada seluruh subyek dalam penelitian ini, baik untuk kasus lesi oral SLE, OLP dan PV, namun data mengenai dosis dan jenis kortikosteroid tidak semuanya terdokumentasi dengan lengkap. Topikal steroid yang paling sering diberikan adalah dexamethasone tablet yang dihaluskan dan dilarutkan dalam air, digunakan untuk berkumur sehari tiga kali. Perlu dilakukan kontrol pasien secara berkala, untuk mengatasi efek samping dengan pemberian obat anti jamur topikal seperti Nystatin in oral suspension.

Predileksi lesi OLP adalah pada mukosa bukal dan lidah serta memiliki kecenderungan bilateral, ${ }^{11,14}$ sejalan dengan hasil penelitian ini yaitu pada mukosa bukal $(66,6 \%)$ dan dorsum lidah $(66,6 \%)$, diikuti oleh mukosa labial $(58,3 \%)$ dan gusi $(41,6 \%)$. Hasil penelitian ini hampir sesuai dengan hasil penelitian yang dilakukan oleh Arisawa, et.al., ${ }^{6}$ yaitu predileksi OLP pada mukosa bukal $(61,2 \%)$, mukosa alveolar atau gusi $(18,4 \%)$, lidah $(14,3 \%)$ dan bibir $(2 \%)$.

Gambaran khas lesi pemfigus berupa bula tidak ditemukan pada penelitian ini, pasien datang dengan lesi erosi dan ulser yang merupakan lesi sekunder akibat bula yang pecah. Bula di dalam rongga mulut mudah pecah karena atap bula yang tipis (split suprabasal) sehingga tidak mudah ditemukan, namun kadang masih ditemukan lesi plak pseudomembran atau sloughing yang merupakan sisa atap bula yang pecah..$^{13,15,16}$ Hasil penelitian ini menemukan bahwa erosi terdapat pada 89,3\% kasus Pemfigus (Gambar 2), sedangkan ulser ditemukan pada $32,1 \%$ kasus. $\mathrm{Hal}$ ini berbeda dengan penelitian yang dilakukan oleh Arisawa et al., menemukan bahwa 100\% kasus disertai dengan ulserasi, $75 \%$ bula dan $50 \%$ menimbulkan rasa sakit. ${ }^{6}$ Perbedaan ini diduga berhubungan dengan perbedaan faktor kedatangan penderita untuk mendapatkan terapi lesi oral. Pada fase akut segera setelah bula pecah adalah menjadi ulser yang seiring berjalan waktu akan menjadi lesi erosi. Penderita yang ditangani oleh bagian IImu Penyakit Mulut di RS. Dr Hasan Sadikin Bandung biasanya sudah dalam kondisi lesi oral kronis yaitu berbentuk erosi dan tidak tampak lesi bula dalam rongga mulutnya.

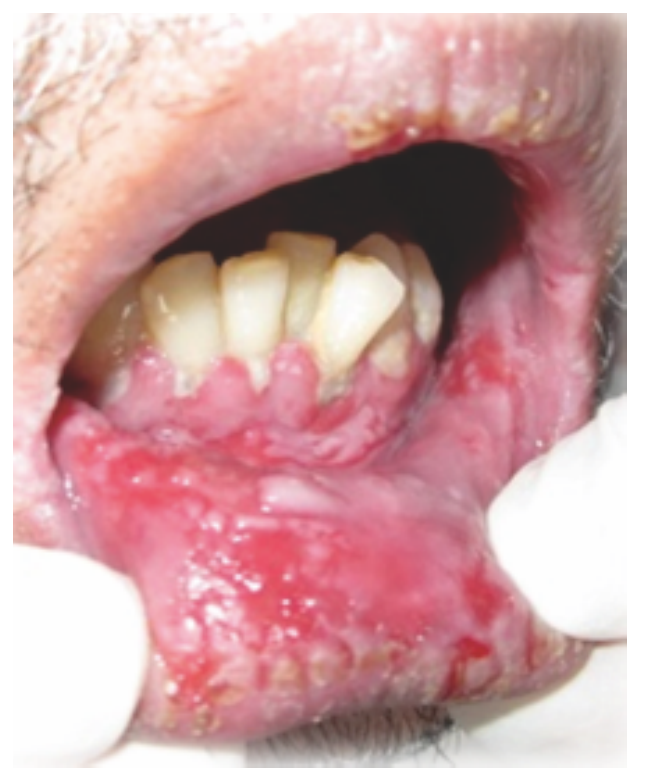

Gambar 2. Gambaran klinis lesi erosi pada pemfigus (doc. RSHS/sub bagian IPM)

Predileksi lesi oral pemfigus pada penelitian ini adalah mukosa bukal $(89,3 \%)$, diikuti oleh dorsum lidah $(82,1 \%)$, mukosa labial $(75 \%)$ dan gusi $(46,4 \%)$. Hasil penelitian ini sedikit berbeda dengan hasil penelitian yang didapatkan oleh 
Arisawa et al., ${ }^{6}$ yaitu predileksi oral pemfigus pada mukosa bukal $(75 \%)$, mukosa alveolar atau gusi $(75 \%)$, palatum molle $(75 \%)$, lidah $(25 \%)$ dan bibir (25\%). Demikian juga menurut laporan yang disampaikan oleh M. Black et al, yaitu predileksi lesi oral Pemfigus adalah mukosa bukal, palatum dan bibir. ${ }^{13}$

Terapi yang diberikan juga berupa kortikosteroid topikal untuk lesi terlokalisir, namun jika lesi ditemukan meluas maka dapat diberikan kostikosteroid sistemik di bawah pengawasan ketat. Lesi oral Pemfigus kadang kurang berespon positif terhadap pemberian imunosupresan sistemik, namun pemberian kortikosteroid topikal atau intralesi dapat membantu. Pada kondisi deskuamatif gingivitis perlu dilakukan peningkatan kebersihan mulut dan menghindari iritasi pada lesi. ${ }^{13}$ Sebagian besar subjek pada penelitian ini menunjukkan hal yang serupa, kondisi lesi oral tidak berespon positif terhadap pemberian imunosupresan sistemik, sehingga ketika kondisi lesi kulit membaik dan pemberian kortikosteroid sistemik dihentikan maka terapi kortikosteroid topikal dilanjutkan sampai lesi oral sembuh.

Obat obatan yang biasa diberikan untuk mengatasi penyakit autoimun seperti kortikosteroid dosis tinggi dan digunakan dalam jangka waktu yang lama dapat mengakibatkan penurunan imunitas sistemik dan akan mempengaruhi imunitas seluler termasuk sel rongga mulut, sehingga muncul penyakit infeksi oportunistik di rongga mulut. Lesi oral yang muncul akibat efek samping pengobatan penyakit autoimun misalnya adalah infeksi jamur dan infeksi virus. Infeksi jamur rongga mulut sebagian besar disebabkan oleh Candida spp. (sebagian besar oleh C.albicans), sehingga disebut Candidiasis oral. Lesi Candidiasis oral dapat berupa plak pseudomembran atau erosi eritema. Infeksi virus yang mengenai rongga mulut di antaranya adalah herpes labialis dan stomatitis herpetika. Lesi oral infeksi virus dapat berupa vesikel dan krusta pada sirkum oral dan sekitar wajah serta dapat juga berupa lesi erosi ulserasi pada daerah intra oral. . $^{1,-10,11,17}$

Terapi yang dapat diberikan untuk mengatasi infeksi rongga mulut dapat berupa obat anti jamur (nystatin in oral suspension, fluconazole, dll), anti virus (hydrocortisone salp), maupun antiseptik (chlorhexidine gluconate, povidone iodine, dll). Obat - obatan tersebut diharapkan dapat mempercepat penyembuhan atau mencegah infeksi menjadi lebih parah, meningkatkan kebersihan mulut pasien dan menurunkan kolonisasi mikroba rongga mulut. ${ }^{1,7-10,11,17}$ Hasil penelitian ini menemukan lesi plak pseudomembran terdapat pada 6 penderita SLE, 7 penderita OLP dan 8 penderita PV. Diagnosis yang ditegakkan adalah Oral Candidiasis yang dipicu oleh penggunaan steroid sistemik dosis tinggi atau jangka panjang.

Terapi yang dapat diberikan untuk mengatasi rasa sakit di rongga mulut dapat berupa obat kumur yang mengandung anti inflamasi (dyphenhydramine hydrochloride atau steroid yang dilarutkan dalam air), anestetikum lokal (benzydamin hydrochloride) atau magic mouthwash (dyphenhydramine hydrochloride atau steroid dalam larutan alumunium magnesium hidroksida). Penggunaan obat obatan topikal yang mengandung steroid harus di bawah pengawasan dan kontrol karena potensi menimbulkan infeksi oportunistik rongga mulut jika digunakan dalam jangka waktu panjang. Jika infeksi dan rasa sakit rongga mulut dapat diatasi, maka intake nutrisi dan hidrasi dapat terjaga, sehingga mempercepat proses penyembuhan baik penyakit autoimun maupun lesi oral serta dapat meningkatkan kualitas hidup penderita., ${ }^{1,6,10-13,18}$ Pada penelitian ini obat - obatan yang diberikan untuk mengatasi rasa sakit lesi oral berupa kortikosteroid yang dilarutkan dalam air digunakan untuk berkumur karena mudah didapatkan dan tersedia di apotek.

Berdasarkan data penelitian keseluruhan ditemukan bahwa lesi oral yang paling sering dijumpai pada penderita penyakit Sistemik Sistemic Lupus Erythematous, Oral Lichen Planus dan Pemfigus Vulgaris adalah erosi. Lesi erosi merupakan manifestasi penyakit autoimun, bukan merupakan efek samping pengobatan kortikosteroid jangka panjang dalam tatalaksana penyakit autoimun. Predileksi lesi oral pada penderita penyakit autoimun adalah mukosa bukal, diketahui bahwa mukosa bukal merupakan 
mukosa dengan epitel tidak berkeratin yang tipis dan sering berkontak langsung dengan gigi, bahan tambalan logam (amalgam) dan makanan yang dapat mengganggu proses penyembuhan lesi oral.

\section{KESIMPULAN}

Lesi oral biasa ditemukan pada penderita penyakit autoimun, baik sebagai manifestasi penyakit atau karena efek samping pengobatan. Lesi oral menimbulkan keluhan berupa rasa sakit yang mengganggu proses mengunyah dan berbicara, sehingga dapat menurunkan daya tahan tubuh, meningkatkan resiko terjadinya penyakit infeksi dan menurunkan kualitas hidup penderita. Lesi oral hendaknya dapat dideteksi melalui pemeriksaan intra oral sebagai prosedur rutin dalam tatalaksana komprehensif penderita penyakit autoimun. Dokter gigi diharapkan dapat berperan dalam mendiagnosis lesi oral dan memberikan terapi yang tepat sehingga dapat meningkatkan kualitas hidup penderita penyakit autoimun.

\section{DAFTAR PUSTAKA}

1. Greenberg MS, Glick M, Ship JA. Burket's oral medicine diagnosis \& treatment $11^{\text {th }}$ edition. BC Decker Inc; 2008. 442 - 447.

2. Jara LJ, Navarro C, Medina G, Vera-Lastra $\mathrm{O}$, Blanco $\mathrm{F}$. Immune-neuroendocrine Interactions and Autoimmune Disease. Clinical and Development Immunology. 2006 June - December; 13(2-4): 109 - 123.

3. Ray S, Sonthalia N, Kundu S, Ganguly S. Autoimmune Disorders: An Overview of Molecular and Cellular Basis in Today's Perspective. J Clin Cell Immunol. 2012. [Internet]. Available from: http://dx.doi. org/10.4172/2155-9899.S10-003, doi:10.4172/2155-9899.S10-003

4. Fairweather D. Autoimmune Disease: Mechanisms [Internet]. Encyclopedia of Life Sciences. John Wiley \& Sons: 2007. Available from: www.els.net Ltd., doi: 10.1002/9780470015902.A0020193 \& 2007.
5. Davidson A, Diamond B. Advances in immunology. N Engl J Med. 2001; 345(5): 340 -350 .

6. Arisawa EAL, Almeida JD, Carvalho YR, Cabral LAG. Clinicopathological analysis of oral mucous autoimmune disease: 27 year study. Med Oral Patol Oral Cir Bucal. 2008; 13(2): $94-97$.

7. Scully C. Oral and maxillofacial medicine: the basis of diagnosis and treatment. Elsevier Limited; 2008. 241 - 248, 261 - 271.

8. Silverman S, Eversole LR, Truelove EL. Essentials of Oral Medicine; 2001. 206 - 217.

9. Langlais RP, Miller CS, Nield-Gehrig JS. Pedoman diagnosis dan penatalaksanaan lesi oral yang sering ditemukan edisi 4; 2009. 207 -225 .

10. Bruch JM, Treister NS. Clinical oral medicine and pathology. Humana Press; 2010. $94-98$, $59-66,139-140$.

11. Field A, Longman L, Tyldesley WR. Tyldesley's oral medicine. Oxford University Press; 2003. $23-28,123-140,165-172$.

12. Kniest G, Stramandinoli RT, Avila LFC, Izidoro ACAS. Frequency of oral lesions diagnosed at the Dental Specialties Center of Tubarao (SC). RSBO. 2011; 8(1): $13-7$.

13. Black M, Mignogna MD, Scully C. Pemphigus vulgaris. Oral Disease. 2005; 11: 119 - 130.

14. Barbosa MO, da Silva AF, de Carvalho AR, Tarquinio SBC, Demarco FF. Oral lichenoid lesions associated with amalgam restorations: report of two cases. Rev Odonto Cienc. 2011; 26(3): $258-261$.

15. Ata-Ali F, Ata-Ali. Pemphigus vulgaris and mucous membrane pemphigoid: Update on etiopathogenesis, oral manifestations and management [Internet]. J Clin Exp Dent. 2011; 3(3): 246 - 250. Available from: http:// www.medicinaoral.com/odo/volumenes/v3i3/ jcedv3i3p246.pdf

16. Davenport S, Chen SY, Miller AS. Pemphigus vulgaris: clinicopathologic review of 33 cases 
Maj Ked Gi Ind. Desember 2016; 2(3): 147-154

ISSN 2460-0164 (print)

ISSN 2442-2576 (online)

in the oral cavity. Int J Periodontics Restorative Dent. 2001; 21: 85 - 90.

17. Gandolfo S, Scully C, Carrozzo M. Oral medicine. Churchill Livingstone, Elsevier; 2006. 101 - 109, 127 - 128.
18. Therapeutic Research Center. Magic mouthwash. Pharmacist's Letter/Prescriber's Letter; 2007. 23(7). 230703. 